\title{
THE INFLUENCE OF ORGANIZATIONAL CULTURE AND ORGANIZATIONAL COMMITMENT TO EMPLOYEE PERFORMANCE THROUGH JOB SATISFACTION AT PT. SEOILINDO PRIMATAMA BEKASI
}

\section{Buchori Nahar}

Student Master of Management

Universitas Krisnadwipayana

Campus Unkris Jatiwaringin

PO BOX 7774/Jat CM Jakarta 1307

Indonesia

\section{Harry Indratjahyo}

Lecturer

Universitas Krisnadwipayana

Campus Unkris Jatiwaringin

PO BOX 7774/Jat CM Jakarta 13077

Indonesia

\section{Guswandi}

Lecturer

Universitas Krisnadwipayana

Campus Unkris Jatiwaringin

PO BOX 7774/Jat CM Jakarta 13077

Indonesia

\begin{tabular}{l}
\hline A R T I C L E I N F O \\
Article history: Article \\
Received \\
Revised \\
Accepted: September, 2020 \\
DOI: $10.47742 /$ ijbssr.v1n1p2
\end{tabular}

\section{A B S T R A C T}

This study aims to: 1) To find out and analyze the influence of organizational culture and organizational commitment to job satisfaction, 2) To know and analyze the influence of organizational culture and organizational commitment on employee performance, 3) To find out and analyze the effect of job satisfaction on employee performance, 4) To find out and analyze the influence of organizational culture and organizational commitment to employee performance through job satisfaction of PT. Seoilindo Primatama Bekasi. The study was conducted at PT. Seoilindo Primatama Bekasi with 73 research samples. The sampling technique uses saturated samples. The data analysis method uses descriptive analysis and quantitative analysis with path analysis.

The results showed that: 1) there is an influence of organizational culture and organizational commitment to job satisfaction, 2) there is an influence of organizational culture and organizational commitment to employee performance, 3) there is an influence of job satisfaction on employee performance, and 4) there is no influence of organizational culture and commitment organization of employee performance through job satisfaction PT. Seoilindo Primatama Bekasi. This means that the direct effect is greater than the indirect effect, the variable job satisfaction cannot mediate between organizational commitment and job satisfaction on employee performance at PT. Seoilindo Primatama Bekasi.

Keywords : Organizational Culture, Organizational Commitment, Job Satisfaction and Employee Performance

\section{Introduction}

Employee performance is a measure set by the company, or in other words the target set by the company for individual employees in a company. The company's performance will b Correspondence Author : * Buchori Nahar, buchori@gmail.com,

maximally achieved by distributing all the targets to be achieved in each of the subsections that exist in the organizational structure of a company. This condition is also experienced by PT. Seoilindo Primatama Bekasi as a fabrication company with 
superior plastic straw products. PT. Seoilindo Primatama Bekasi, which was founded in 1989, has unquestioned operational hours among its competitors. However, this condition is not believed to be the superiority of PT. Seoilindo Primatama Bekasi, which in recent years has decreased in production which tends to decline every year. This phenomenon occurs due to many factors, such as the difficulty of importing quality plastic pellets to the human resources who have not been able to utilize the facilities and technology used by the company. If we look further, the use of machines and technology used is expected to help companies streamline operational costs by reducing working hours and employee usage. However, on the other hand, the conditions that occur are the use of high technology which is unable to support the achievement of the targets set by the company. One of the causes is that the target of each employee has not been achieved, operationally achieving the performance of each employee will encourage the achievement of company performance or it can be said that the better the performance produced by each employee, the better the company's productivity.

Employee performance appraisal is a routine activity carried out by the company with a predetermined time. The results of the performance appraisal can be used as the basis for the size of the company in providing compensation or remuneration for employees. Compensation for employees is an important factor for the achievement of employee performance where everyone has a motive or desire to work, namely to be able to meet the needs of life and to increase their welfare. Compensation has an important role for employees which can be seen from the provisions in the provision of compensation for both employees regulated in government regulations and followed up by company regulations. However, many factors have become unsuccessful in providing compensation for employees, such as fairness and fairness, this mismatch generally arises from the employee's side, which lies in the high expectations the company has for remuneration provided.

A company that is growing rapidly has a good organizational culture that is carried out by employees, company management, and stakeholders that take place continuously. The implementation of a good organizational culture following the wishes of employees and management will have an impact on company development.

Organizational culture is a value held by organizational members who will become enthusiastic in developing the organization. Waridin and Masrukhin (2006) state that organizational culture is a value system that is obtained and developed by the organization and the habit patterns and basic philosophy of its founders, which are formed into rules that are used as guidelines in thinking and acting in achieving organizational goals.

Kusmono (2005) states that organizational culture affects employee performance, especially employees in the production division. The unit of analysis is production employees in the wood processing industry sub-sector in East Java. Other results also state that motivation has an effect on performance by 0.003 and organizational culture has an effect on performance. The results of this study can be used by future researchers as research material in the field of organizational behavior science or similar sciences.

\section{Literature Review}

\section{Employee Performance}

The definition of performance according to Siswanto (2002: 235) states that performance is the result of work in quality and quantity achieved by a person in carrying out the tasks and jobs assigned to him. Rivai (2005: 309) says that performance is a real behavior that is displayed by each person as a work achievement that is produced by employees according to their role in the company. The results of the work or activities of an employee in quality and quantity in an organization to achieve goals in carrying out the tasks and work assigned to him.

Performance measurement according to Dharma (2003: 355) which is quoted from saying that almost all ways of measuring performance consider the following:

1. Quantity, namely the amount that must be completed or achieved.

2. Quality, namely the quality that must be produced (whether good or not). The qualitative measurement of output reflects the measurement or level of satisfaction, namely how well it is completed

3 . Punctuality, that is, according to the planned time.

Meanwhile, according to Mathis (2006: 78) which is an indicator in measuring employee performance or achievement are as follows:

a. Work quantity, namely the volume of work produced under normal conditions.

b. Quality of work, which can be in the form of neatness, accuracy, and linkage of results without neglecting the volume of work.

c. Time utilization, namely the use of the working period adjusted to the policy of the company or government institution.

d. Cooperation, namely the ability to handle relationships with other people at work.

\section{Organizational Culture}

Robbins (2001) states that organizational culture is a system of shared meaning within an organization that determines at a higher level of how employees act. Organizational culture is a value system that is believed by all members of the organization and is studied and applied and developed on an ongoing basis that functions as a whole system. Robbins (2001) states organizational culture studies to a system of shared meaning held by members that distinguish the organization from other organizations. This system of shared meaning is, on closer analysis, a set of key characteristics that the organization value. Furthermore, Robbins (2001) argues that: "Organizational culture as the dominant values disseminated in the organization becomes the work philosophy of employees which becomes a guide for organizational policies in managing employees and customers. 
Organizational culture as a series of values and norms that control organizational members interact with others and with suppliers, consumers, and others outside the organization. Organizational culture consists of end states that the organization strives to achieve (terminal values) and models encouraging organizational behavior (instrumental values). Ideally, instrumental value helps the organization reach its terminal goals. Different organizations have different cultures because they process different instrumental and terminal value arrangements.

Organizational culture has a broad meaning. According to Dessler (2008), organizational culture is a characteristic of the values, traditions, and behavior of employees in the company. According to Luthans (2000), organizational culture is the norms and values that direct the behavior of organizational members. Each member will behave following the prevailing culture to be accepted by the environment.

Schein in Luthan (2000) defines organizational culture as a pattern of basic assumptions that are found, created, or developed by a particular group with the intention that organizations learn to overcome or cope with problems that arise as a result of external adaptation and internal integration that has been running, good enough so that it needs to be taught to new members as the correct way to understand, think and feel pleased with these problems. Denison and Misra (1995) formulated indicators of organizational culture as follows: (1) mission, (2) consistency, (3) adaptability, and (4) involvement.

\section{Organizational Commitment}

According to Robbins and Judge (2008: 100) organizational commitment is a condition in which employee sides with a particular organization and its goals and desires to maintain membership in that organization. Thus, high job involvement means taking sides with an individual's particular job, while high organizational commitment means siding with the organization that recruits that individual.

Meanwhile, according to Moorhead and Griffin (2013: 73) organizational commitment is an attitude that reflects the extent to which an individual knows and is tied to the organization. A highly committed individual is likely to see himself as a true member of the organization. Meanwhile, according to Kreitner and Kinicki (2015: 165) that organizational commitment reflects the level at which a person recognizes an organization and is bound to its goals.

It can be concluded that organizational commitment is the psychological state of an individual that is related to strong belief, belief, and acceptance of the goals and values of the organization, a strong willingness to work for the organization, and the extent to which he wants to be a member of the organization.

Robbins and Judge (2008: 101) state that there are three separate dimensions of organizational commitment:

1. Affective commitment is an emotional feeling for an organization and a belief in its values. For example, a Petco employee may have an active commitment to his company because of his involvement with animals.
2. Sustainable commitment is the perceived economic value of staying in an organization when compared to leaving the organization. An employee may commit to an employer because he is highly paid and they believe that resigning from the company will destroy his family.

3. Normative commitment is an obligation to survive in the organization for moral and ethical reasons. For example, an employee spearheading a new initiative might stick with an employer because he feels he is leaving someone in difficult circumstances when he leaves.

\section{Job Satisfaction}

Job satisfaction is the level of pleasure that a person feels for his role or job in the organization. The level of individual satisfaction that they are rewarded in kind from various aspects of the job situation of the organization where they work. So job satisfaction concerns the psychological individual in the organization, which is caused by the state he feels from his environment.

Handoko (2004: 193-194) suggests that job satisfaction is a pleasant or unpleasant emotional state with employees seeing their work. The time/duration of completion is a reflection of a person's feelings about his job. This can be seen from the positive attitude of employees towards work and everything in their environment.

The level of job satisfaction is one of the factors that influence work performance because that ultimately affects organizational effectiveness. And also employee job satisfaction is not enough to only be given incentives but employees also need motivation, recognition from their superiors for their work results, work situations that are not monotonous and there are opportunities to take initiative and be creative. Resources consisting of human resources, facilities, and infrastructure as well as financing determine the success of an organization to carry out its duties or operate properly in achieving its goals. The important aspect that supports success is none other than the availability of adequate resources. In line with this, Notoatmojo (2012) argues that: the development of a nation requires basic assets called resources, both natural resources and human resources.

Thoha (2013: 98) states that the model developed by Weisbord, namely: goals, structure, rewards, work procedures, relationships, and leadership will affect organizational effectiveness if efforts are not made to develop the organization. Umar (2008) states that job satisfaction is a person's feeling and assessment of his job, especially regarding his working conditions, concerning whether the job can meet the expectations of his needs and wants.

\section{Research Methods}

\section{Object of Research}

The research was conducted on employees of PT. Seoilindo Primatama Bekasi

Research Design 
This study uses an explanatory analysis approach. This independent variable to the dependent variable. The relationship means that each variable presented in the hypothesis will be between variables can be described in the form of a path analysis observed through testing the causal relationship of the diagram as follows:

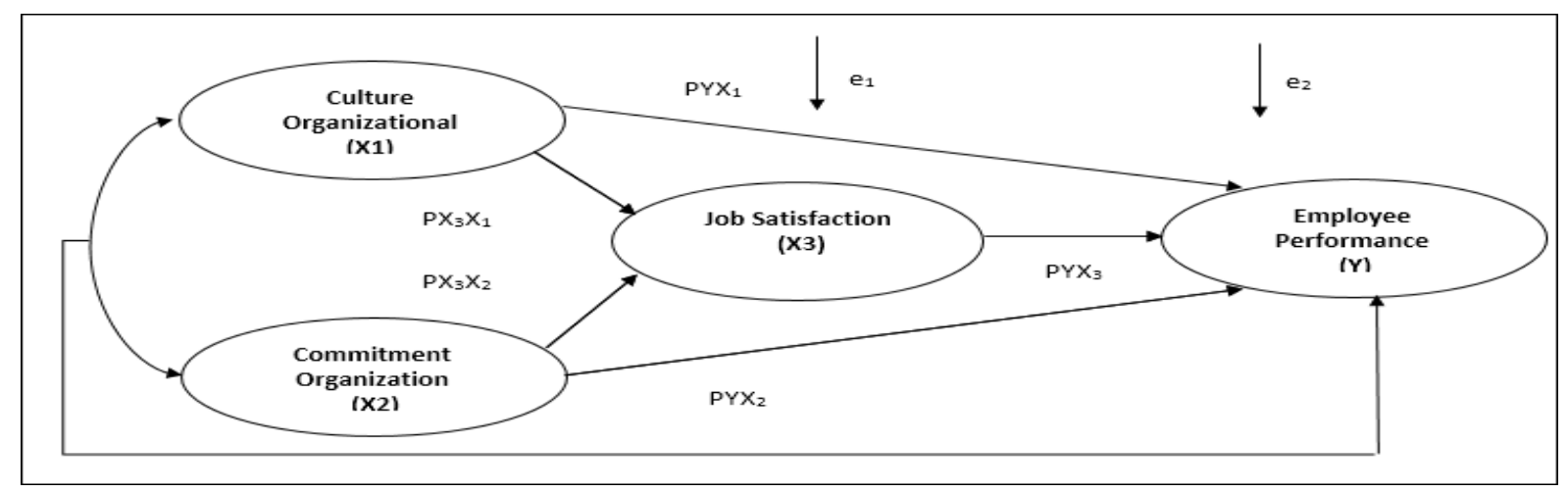

Figure 1. Overall Path Analysis

\section{Population and Sample}

The population is a generalization area consisting of objects/subjects that have certain quantities and characteristics set by the researcher for the study and then draw conclusions (Sugiyono, 2005). The sample is a part of the population to represent the entire population (Surakhmad, 1990).

The sample used in this study is the number of employees of the company as many as 275 people. The number of samples was taken with the formula Slovin $=275 /(1+275 \times 0.12)=73$ people. This sampling uses simple random sampling.

\section{Data Analysis}

Vol: 1, Issue: 1

September/2020

https://ijbssrnet.com/index.php/ijbssr

DOI: 1 10.47742/ijbssr.v1n1p2

Table 1. Simultaneous Test Results for Organizational Culture and Organizational Commitment to Job Satisfaction

\begin{tabular}{llrrrr}
\multicolumn{7}{c}{ Model Summary $^{\mathbf{b}}$} \\
\hline Model & R & R Square & Adjusted R & Std. Error of the & Durbin- \\
Square & Estimate & Watson \\
\hline 1 & $.725^{\text {a }}$ & .525 & .512 & 2.12290 & 1.888 \\
\hline
\end{tabular}

a. Predictors: (Constant), X2, X1

b. Dependent Variable: X3

Source: Primary data processed, 2020

Table 1, shows the R2 (R Square) value of 0.525 . The explained by organizational culture and organizational value of R2 is used in calculating the value of the e1 coefficient. commitment. Magnitude: The coefficient of e1 $=0.689$ The coefficient el is a variant of job satisfaction that is not

Table 2. Job Satisfaction Regression Analysis

\begin{tabular}{|c|c|c|c|c|c|c|}
\hline \multirow{2}{*}{\multicolumn{2}{|c|}{ Model }} & \multicolumn{2}{|c|}{$\begin{array}{l}\text { Unstandardized } \\
\text { Coefficients }\end{array}$} & \multirow{2}{*}{$\begin{array}{c}\text { Standardized } \\
\text { Coefficients } \\
\text { Beta } \\
\end{array}$} & \multirow[b]{2}{*}{$\mathrm{t}$} & \multirow[b]{2}{*}{ Sig. } \\
\hline & & B & Std. Error & & & \\
\hline 1 & (Constant) & 6.538 & 1.214 & & 5.386 & .000 \\
\hline & $\mathrm{X} 1$ & .303 & .174 & .278 & 1.739 & .087 \\
\hline & $\mathrm{X} 2$ & .658 & .223 & .472 & 2.951 & .004 \\
\hline
\end{tabular}

Source: Primary data processed, 2020 
http://iarpnet.org/

Based on Table 2, it can be seen that the regression equation is as follows:

$\mathrm{X}_{3}=\mathrm{b}_{1} \mathrm{X}_{1}+\mathrm{b}_{2} \mathrm{X}_{2}+\mathrm{e}_{1}$

$\mathrm{X}_{3}=0,278 \mathrm{X}_{1}+0,472 \mathrm{X}_{2}+0,689 \mathrm{e}_{1}$

The equation shows that:

- Every time there is an increase in 1 organizational culture, an increase in job satisfaction will be followed by 0.278 .
Vol: 1, Issue: 1

September $/ 2020$

https://ijbssrnet.com/index.php/ijbssr

DOI: $10.47742 /$ ijbssr.v1n1p2

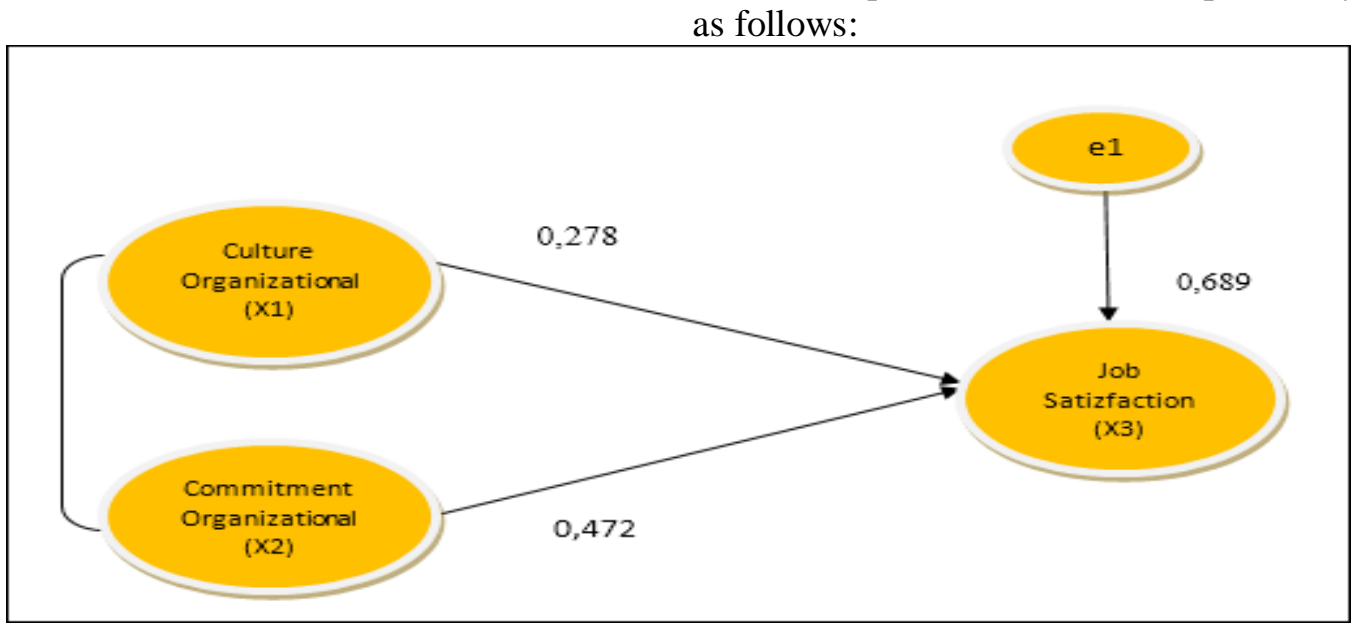

Source: Primary data processed, 2020

Figure 2. Substructure Equations 1

2. Analysis of the Influence of Organizational Culture, The results of the regression analysis of the influence of Organizational Commitment and Job Satisfaction on Employee organizational culture, organizational commitment and job Performance satisfaction on employee performance can be seen in Table 3 below:

Table 3. Simultaneous Test Results for Organizational Culture, Organizational Commitment, Job Satisfaction and Employee Performance

Model Summary ${ }^{b}$

\begin{tabular}{llrrrr}
\hline Model & R & R Square & $\begin{array}{r}\text { Adjusted } \\
\text { R Square }\end{array}$ & $\begin{array}{l}\text { Std. Error of } \\
\text { the Estimate }\end{array}$ & $\begin{array}{l}\text { Durbin- } \\
\text { Watson }\end{array}$ \\
\hline 1 & $.841^{\mathrm{a}}$ & .706 & .694 & 1.83701 & 2.004 \\
\hline
\end{tabular}

a. Predictors: (Constant), X3, X1, X2

b. Dependent Variable: Y

Table 3 shows the R2 (R Square) value of 0.706. The not explained by organizational culture, organizational value of R2 is used in calculating the value of the e 2 coefficient. commitment and job satisfaction. Magnitude: The coefficient of The coefficient $\mathrm{e} 2$ is a variant of employee performance that is $\mathrm{e} 2=0.542$

Table 4. Employee Performance Regression Analysis

\begin{tabular}{|c|c|c|c|c|c|c|}
\hline \multirow{2}{*}{\multicolumn{2}{|c|}{ Model }} & \multicolumn{2}{|c|}{$\begin{array}{c}\text { Unstandardized } \\
\text { Coefficients }\end{array}$} & \multirow{2}{*}{$\begin{array}{c}\text { Standardized } \\
\text { Coefficients } \\
\text { Beta } \\
\end{array}$} & \multirow[b]{2}{*}{$\mathrm{t}$} & \multirow[b]{2}{*}{ Sig. } \\
\hline & & $\mathrm{B}$ & Std. Error & & & \\
\hline \multirow[t]{4}{*}{1} & (Constant) & .605 & 1.249 & & .484 & .001 \\
\hline & $\mathrm{X} 1$ & 279 & .154 & .235 & 1.814 & .001 \\
\hline & $\mathrm{X} 2$ & .203 & .205 & .133 & 993 & .003 \\
\hline & X3 & .837 & .103 & .766 & 8.094 & .000 \\
\hline
\end{tabular}

Source: Primary data processed, 2020

$\mathrm{Y}=0,235 \mathrm{X}_{1}+0,133 \mathrm{X}_{2}+0,766 \mathrm{X}_{3}+0,542 \mathrm{e}_{2}$

Based on Table 4, it can be seen that the

The equation shows that: regression equation is as follows: $\mathrm{Y}=\mathrm{b}_{1} \mathrm{X}_{1}+\mathrm{b}_{2} \mathrm{X}_{2}+\mathrm{b}_{3} \mathrm{X}_{3}+\mathrm{e}_{2}$ 
a. Every time there is an increase in 1 unit of organizational culture, an increase in employee performance will be followed by 0.235 .

b. Every time there is an increase of 1 unit of organizational commitment, an increase in employee performance will be followed by 0.133 .
Vol: 1, Issue: 1

September $/ 2020$

https://ijbssrnet.com/index.php/ijbssr DOI: 10.47742/ijbssr.v1n1p2 c. Every time there is an increase in 1 unit of job satisfaction, an increase in employee performance will be followed by 0.766 .

So that from equation (2) it can be seen that if the organizational culture then employee performance will increase. If organizational commitment increases, employee performance will also increase. Likewise, if job satisfaction increases, employee performance will also increase.

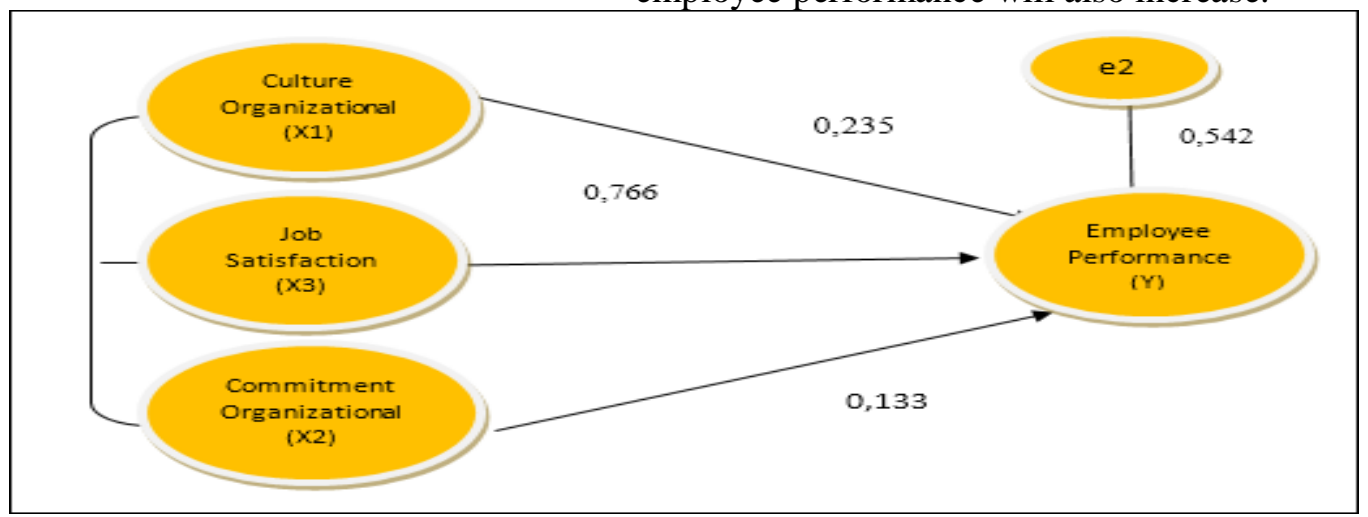

Figure 3. Substructure Equation 2

Based on equations (1) and (2), a path analysis model is obtained as follows:

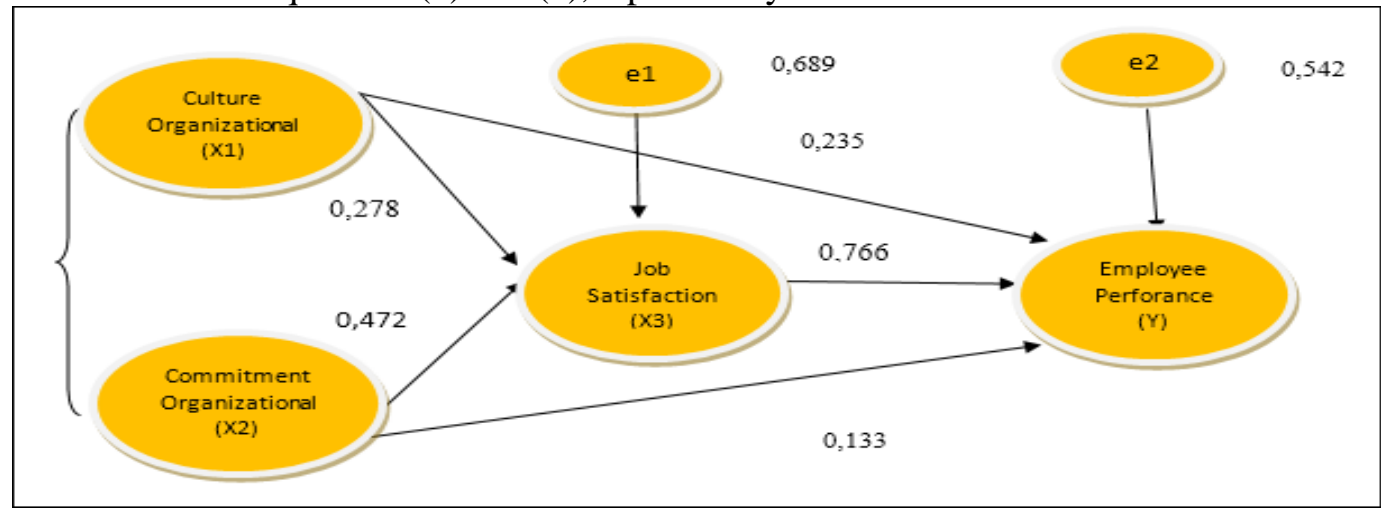

Figure 4. Path Analysis Model

Hypothesis Test

1. The Influence of Organizational Culture and a test of each variable: Organizational Commitment on Job Satisfaction

Table 5. T-test results. The Effect of Organizational Culture and Organizational Commitment on Job Satisfaction

\begin{tabular}{|c|c|c|c|c|c|c|}
\hline \multirow{2}{*}{\multicolumn{2}{|c|}{ Model }} & \multicolumn{2}{|c|}{$\begin{array}{l}\text { Unstandardized } \\
\text { Coefficients }\end{array}$} & \multirow{2}{*}{$\begin{array}{c}\text { Standardized } \\
\text { Coefficients } \\
\text { Beta } \\
\end{array}$} & \multirow[b]{2}{*}{$\mathrm{t}$} & \multirow[b]{2}{*}{ Sig. } \\
\hline & & $\mathrm{B}$ & Std. Error & & & \\
\hline \multirow[t]{3}{*}{1} & (Constant) & 6.538 & 1.214 & & 5.386 & .000 \\
\hline & $\mathrm{X} 1$ & .303 & .174 & .278 & 1.739 & .087 \\
\hline & $\mathrm{X} 2$ & .658 & .223 & .472 & 2.951 & .004 \\
\hline
\end{tabular}

Source: Primary data processed, 2020

From Table 5, it is found that the t-count value of the satisfaction. Thus the first hypothesis is tested and proven. Based organizational culture variable is 1.739 , while the t-table value is on the results of the path analysis shows that organizational 1.993 and the t-count value of the organizational commitment culture and organizational commitment have an impact on variable is 2.951, while the t-table value is 1.993. Thus t-count> increasing job satisfaction of employees of PT. Seoilindo t-table (1.739> 1.993) and (2.951> 1.993), thus H0 is rejected and Primatama Bekasi. The results of the study are in line with the H1 is accepted at the real level. This concludes that results of previous studies conducted by Fadel Yamin (2017), organizational culture and organizational commitment affect job 
Vol: 1, Issue: 1

September/2020

https://ijbssrnet.com/index.php/ijbssr

DOI: $10.47742 /$ ijbssr.v1n1p2

http://iarpnet.org/

Lukman (2017), Arif Burhan, Ari Pradhanawati, \& Reni Shinta Dewi (2013), Budiman Imran (2018).

2. The Influence of Organizational Culture Organizational Commitment on Employee Performance

Table 6. T-test results. The Effect of Organizational Culture and Organizational Commitment on Employee Performance

\begin{tabular}{|c|c|c|c|c|c|c|}
\hline \multirow{2}{*}{\multicolumn{2}{|c|}{ Model }} & \multicolumn{2}{|c|}{$\begin{array}{c}\text { Unstandardized } \\
\text { Coefficients }\end{array}$} & \multirow{2}{*}{$\begin{array}{c}\text { Standardized } \\
\text { Coefficients } \\
\text { Beta } \\
\end{array}$} & \multirow[b]{2}{*}{$\mathrm{t}$} & \multirow[b]{2}{*}{ Sig. } \\
\hline & & B & Std. Error & & & \\
\hline \multirow[t]{3}{*}{1} & (Constant) & 6.078 & 1.456 & & 4.174 & .000 \\
\hline & X1 & .532 & .209 & .448 & 2.550 & .013 \\
\hline & $\mathrm{X} 2$ & .348 & .267 & .228 & 1.300 & .198 \\
\hline
\end{tabular}

Source: Primary data processed, 2020

The t-test results for the organizational culture variable obtained the t-count value $=2.550$ and the t-table value of 1.993 and the organizational commitment variable obtained the t-count value of 1.300 , and the t-table value of 1.993 . This means that $t-$ count> t-table $(2.550>1.993)$ for the organizational culture variable $\mathrm{H} 0$ is rejected and $\mathrm{H} 1$ is accepted. However, for the organizational commitment variable $(1,300<1,993)$ which means that $\mathrm{H} 0$ is rejected and $\mathrm{H} 1$ is rejected. This concludes that organizational culture affects employee performance and Organizational Commitment has no effect on employee performance. Thus the second hypothesis is untested and unproven.

Based on the results of the path analysis shows that To test the effect of job satisfaction on employee performance, a organizational culture and organizational commitment have an t-test is used. The following are the results of the t-test:

Table 7. The Effect of Job Satisfaction on Employee Performance

Coefficients $^{\mathrm{a}}$

\begin{tabular}{|c|c|c|c|c|c|}
\hline \multirow[b]{2}{*}{ Model } & \multicolumn{2}{|c|}{$\begin{array}{c}\text { Unstandardized } \\
\text { Coefficients }\end{array}$} & \multirow{2}{*}{$\begin{array}{c}\text { Standardized } \\
\text { Coefficients }\end{array}$} & \multirow[b]{2}{*}{$\mathrm{t}$} & \multirow[b]{2}{*}{ Sig. } \\
\hline & $\mathrm{B}$ & Std. Error & & & \\
\hline $1 \quad$ (Constant) & 1.023 & 1.237 & & .827 & .411 \\
\hline $\mathrm{X} 3$ & .909 & .072 & .832 & 12.617 & .000 \\
\hline
\end{tabular}

a. Dependent Variable: Y

Source: Primary data processed, 2020

The t-test results for the job satisfaction variable obtained the t-count value of 12.617 and the t-table value of 1.993. This means that $\mathrm{t}$-count $>\mathrm{t}$-table (12.617> 1.993), which means that $\mathrm{H} 0$ is rejected and $\mathrm{H} 1$ is accepted. This concludes that job satisfaction affects employee performance. Thus the third hypothesis is tested and proven. Based on the results of the path analysis shows that job satisfaction has an impact on improving the performance of employees of PT. Seoilindo Primatama Bekasi. The results of the study are in line with the results of previous research conducted by Fadel Yamin (2017), Lukman (2017), Arif Burhan, Ari Pradhanawati, \& Reni Shinta Dewi (2013), Budiman Imran (2018), Wagiman S and Himawan Arif Sutanto (2018), Prasiska Ramadyaning Utami, E. Maria Kristine Sitohang (2019), Stefanie Inggried Gorap, Siti Haerani, Wardhani Hakim (2018).
4.The Influence of Organizational Culture and Organizational Commitment on Employee Performance Through Job Satisfaction

$X_{1} \rightarrow X_{3} \rightarrow Y=\left(\rho x_{3} x_{1}\right) x\left(\rho x_{3}\right)=0,278 \times 0,766=0,213$

$\mathrm{X}_{2} \rightarrow \mathrm{X}_{3} \rightarrow \mathrm{Y}=\left(\rho \mathrm{x}_{3} \mathrm{X}_{2}\right) \mathrm{x}\left(\rho \mathrm{yx}_{3}\right)=0,472 \mathrm{x} 0,766=0,362$

In the organizational culture variable, the indirect effect value is obtained from the path coefficient value $\rho \times 3 \times 1$ multiplied by the path coefficient value $\rho y x 3$. The multiplication result shows that the value of the indirect effect coefficient is smaller than the value of the direct effect coefficient. In the organizational commitment variable, the indirect effect value is obtained from the path coefficient value $\rho \times 3 \times 2$ multiplied by the path coefficient value $\rho y x 3$. The multiplication result shows that the value of the indirect effect coefficient is smaller than the value of the direct effect coefficient. 
This shows that job satisfaction cannot mediate, namely organizational culture and organizational commitment in influencing employee performance. Based on the results of path analysis shows that organizational culture and organizational commitment to employee performance through employee job satisfaction of PT. Seoilindo Primatama Bekasi has no impact on improving employee performance. The results of the study reject the results of previous research conducted by Fadel Yamin (2017), Lukman (2017), Arif Burhan, Ari Pradhanawati, \& Reni Shinta Dewi (2013), Budiman Imran (2018), Wagiman S and Himawan Arif Sutanto (2018), Prasiska Ramadyaning Utami, E. Maria Kristine Sitohang (2019), Stefanie Inggried Gorap, Siti Haerani, Wardhani Hakim (2018), I Wayan Suparta, I Komang Ardana (2019), I Gede Putu Kawiana, Luh Komang, Candra Dewi, Luh Kadek Budi Martini, Ida Bagus Raka Suardana (2018), Kardinah Indrianna Meutia, Cahyadi Husada (2019).

\section{Total Effect}

- The influence of organizational culture on employee performance through job satisfaction

$\mathrm{X} 1 \rightarrow \mathrm{X} 3 \rightarrow \mathrm{Y}=\rho \mathrm{yx} 1+\{(\rho \mathrm{x} 3 \mathrm{x} 1) \mathrm{x}(\rho \mathrm{yx} 3)\}=0.278+0.766$ $=1.044$

- The total influence arising from an organizational culture on employee performance through job satisfaction is 1.044 .

\section{Conclusions and Recommendations \\ Conclusion}

a. Based on the results of the path analysis shows that the organizational culture and organizational commitment to the job satisfaction of employees of PT. Seoilindo Primatama Bekasi has an impact on increasing job satisfaction.

b. Based on the results of the path analysis shows that organizational culture has an impact on improving employee performance.

c. Based on the results of the path analysis, it shows that job satisfaction has an impact on improving employee performance.

d. Based on the results of the path analysis, it shows that organizational culture and organizational commitment to employee performance through job satisfaction have no impact on improving employee performance.

\section{Recommendations}

This research is expected to be useful for PT. Seoilindo Primatama Bekasi in improving company development by considering:

a. The results of this study are expected to be used as a contribution of thought to, by paying attention to organizational culture variables, especially for the consistency indicator which gives the lowest value to the formation of organizational culture variables, namely using which employees must be able to adapt to the culture applied by the organization.

b. The results of this study are expected to be used as a thoughtful contribution to PT. Seoilindo Primatama Bekasi, taking into
The influence of organizational commitment on employee performance through job satisfaction

$\mathrm{X} 2 \rightarrow \mathrm{X} 3 \rightarrow \mathrm{Y}=\rho \mathrm{yx} 2+\{(\rho \mathrm{x} 3 \mathrm{x} 2) \mathrm{x}(\rho \mathrm{yx} 3)\}=0.472+0.766$ $=1.238$

- The total influence that arises from work organizational commitment to employee performance through job satisfaction is 1.238 .

- The influence of organizational culture on employee performance $: \mathrm{X} 1 \rightarrow \mathrm{Y}=$ pyx $1=0.235$

- The total influence arising from an organizational culture on employee performance is 0.235

- The influence of organizational commitment on employee performance $: \mathrm{X} 2 \rightarrow \mathrm{Y}=\rho \mathrm{yx} 2=0.133$

- The total influence arising from an organizational commitment to employee performance is 0.133

- Effect of job satisfaction on employee performance : X3 $\rightarrow$ $\mathrm{Y}=$ pyx3 $=0.766$

- The total effect of job satisfaction on employee performance is 0.766 .

- The effect of residual coefficient variables on job satisfaction: The coefficient of e1 $=0.689$

- The effect of residual coefficient variables on employee performance: The coefficient of e $2=0.542$

account the variables of organizational commitment, especially for indicators of affective commitment, continuance commitment, a normative commitment which gives the lowest score for the formation of organizational commitment variables, namely affective commitment, sustainable commitment, and normative commitment. Namely that the employees of PT. Seoilindo Primatama Bekasi must have a good emotional feeling towards the organization, must have the belief that joining to work in the organization is appropriate, and must believe that the organization will provide benefits in the future.

c. The results of this study are expected to be used as a thoughtful contribution to PT. Seoilindo Primatama Bekasi, by paying attention to job satisfaction variables, especially for indicators of enjoying their work, which gives the lowest value for job satisfaction variables, namely by the company giving employees to enjoy their work so that they can devote their time to work following applicable regulations and have a sense of belonging. d. The results of this study are expected to be used as a contribution of thought for PT. Seoilindo Primatama Bekasi, by paying attention to employee performance variables, especially for cooperation indicators that give the lowest score for employee performance variables, namely by way of employees working together with leaders in achieving common goals, eliminating the fear of leadership, if there are problems in deliberation with management. 


\section{References}

Agus, Dharma. (2003). Manajemen Supervisi: Petunjuk Praktis Bagi Para Supervisor. Edisi Revisi. Cetakan kelima. Jakarta: RajaGrafindo Persada.

Ambar Teguh Sulistiyani dan Rosidah, (2003), Manajemen Sumber Daya Manusia, Graha Ilmu, Yogyakarta.

Arif Burhan, Ari Pradhanawati, \& Reni Shinta Dewi. (2013). Pengaruh Budaya Organisasi, Dan Komitmen Organisasi Terhadap Kinerja Karyawan Dengan Mediasi Kepuasan Kerja Pada PT. BPR Setia Karib Abadi Semarang. Diponegoro Journal Of Social And Politic. Tahun 2013, Hal. 1-9 http://ejournals1.undip.ac.id/index.php/

Basri, A. F. M., dan Rivai, V. (2005). Performance appraisal. Jakarta: PT Raja. Grafindo Persada.

Budi, Setiyawan dan Waridin. (2006). Pengaruh Disiplin Kerja Karyawan dan Budaya Organisasi Terhadap Kinerja di Divisi Radiologi RSUP Dokter Kariadi, Semarang: JRBI. Vol 2. No $2 . \quad$ Hal: $181-198$. http://journal.student.uny.ac.id/ojs/index.php/jmbi/article/view/5059

Corey, Gerald. (2005). Teori dan praktek dari konseling dan psikoterapi. Terjemahan oleh E. Koeswara. Jakarta: ERESCO.

Dessler, Gary, (2008), Human Resources Management, $8^{\text {th }}$ Edition, Prentice Hall, International Inc.

Fred Luthans. (2000). Perilaku Organisasi - Edisi Sepuluh, Penerbit Andi, Yogyakarta.

Handoko, T. Hani. (2003). Manajemen. Edisi 2 . Penerbit BPFE Yogyakarta, Yogyakarta.

I Gede Putu Kawiana, Luh Komang, Candra Dewi, Luh Kadek Budi Martini, Ida Bagus Raka Suardana, (2018). The Influence of Organizational Culture, Employee Satisfaction, Personality, and Organizational Commitment towards Employee Performance. International Research Journal of Management, IT \& Social Sciences. Vol. 5 No. 3, May 2018, pages: 35 45. https://ojs.unud.ac.id/index.php/Manajemen/article/view/45788.

I Wayan Suparta, I Komang Ardana, (2019), Pengaruh Budaya Organisasi Dan Komitmen Organisasi Terhadap Kepuasan Kerja Karyawan PT. Pengembangan Pariwisata Indonesia Persero, E-Jurnal Manajemen, Vol. 8, No. 6, 2019 :3446-472. https://ojs.unud.ac.id/index.php/Manajemen/article/view/45788

Imran, Budiman. (2018). Organizational Culture, Organizational Commitment And Job Satisfaction In Hospital Employees In West Sulawesi. Business and Entrepreneurial Review Vol.18, No.2, October. 2018. https://pdfs.semanticscholar.org/6c5e/8b247d811382dd9842d666bc07824877750a.pdf

Irianto, Yusuf, (2012). Tema-Tema Pokok Manajemen Sumber Daya Alam, Penerbit Insan Cendikiawan, Surabaya

Kardinah Indrianna Meutia, Cahyadi Husada, (2019). Pengaruh Budaya Organisasi Dan Komitmen Organisasi Terhadap Kinerja Karyawan. Jurnal Riset Manajemen dan Bisnis (JRMB) Fakultas Ekonomi UNIAT Vol.4, No.1 Februari 2019 : 119 - 126. https://jrmb.ejournal-feuniat.net/index.php/JRMB/article/view/246

Kreitner dan Kinicki, (2015), Organizational Behavior. 8 th Edition. Boston : McGraw-Hill.

Kusmono, H. Teman. (2005). Pengaruh Budaya Organisasi Terhadap Motivasi dan Kepuasan Kerja serta Kinerja Karyawan pada Sub Sektor IndustriPengolahan Kayu Skala Menengah di Jawa Timur. Jurnal Manajemen dan Kewirausahaan, Vol. 7 No. 2 , September 2005: 171-188. http://jurnalmanajemen.petra.ac.id/index.php/man/article/view/16362

L. Mathis, Robert dan John H. Jackson, , 2006. Human Resource Management (Management Sumber Daya Manusia), Jakarta: salemba empat.

Lukman, (2017). Pengaruh Budaya Organisasi Dan Komitmen Organisasi Terhadap Kepuasan Kerja Dalam Peningkatan Kinerja Karyawan (Studi Kasus Karyawan BSI Kampus Pemuda Jakarta), Jurnal Komunikasi, Volume VIII Nomor 3, September 2017. https://ejournal.bsi.ac.id/ejurnal/index.php/jkom/article/view/3095

Masrukhin dan Waridin. (2006). Pengaruh Motivasi Kerja, Kepuasan Kerja, Budaya Organisasi dan Kepemimpinan terhadap Kinerja Pegawai, Jurnal Ekonomi \& Bisnis, Vol. 7, No. 2.. http://eprints.undip.ac.id/29481/1/Jurnal_Wilhelmus.pdf

Miner, John. B. (2005). Organizational Behavior: Performance and Productivity, First Edition, random House, Inc. New York.

Noto Atmodjo, Soekidjo, (2012). Pengembangan Sumber Daya Manusia, Cetakan Ke-2, Penerbit Reneka Cipta, Jakarta.

Prasiska Ramadyaning Utami, E. Maria Kristine Sitohang, (2019). Effect of Organizational Culture Intensity On Job Satisfaction, Jurnal Administrasi Kesehatan Indonesia Volume 7 No 2 December. $2019 . \quad$ https://ejournal.unair.ac.id/JAKI/article/view/10326

Robbins, Stephen P. (2001). Perilaku Organisasi: Konsep, Kontroversi, Aplikasi, Jilid 1, Edisi 8, Prenhallindo, Jakarta. 
https://ijbssrnet.com/index.php/ijbssr DOI: $10.47742 /$ ijbssr.v1n1p2

Robbins, Stephen P. dan Timothy A. Judge. (2008). Perilaku Organisasi. Edisi ke-12, Jakarta: Salemba Empat.

Siswanto, (2005), Pengantar Manajemen, Jakarta, Bumi Aksara.

Stefanie Inggried Gorap, Siti Haerani, Wardhani Hakim, (2018), Pengaruh Budaya Organisasi, Komitmen Organisasi, Dan Kompensasi Terhadap Kinerja Pegawai Melalui Kepuasan Kerja Sebagai Variabel Intervening (Studi Pada Dinas Kesehatan Daerah Kota Tomohon). Hasanuddin Journal of Applied Business and Entrepreneurship. https://media.neliti.com/media/publications/279986-the-effect-of-organizational-culture-org-965ba0ca.pdf

Sugiyono. (2005). Memahami Penelitian Kualitatif. Bandung: CV. Alfabeta.

T. Hani Handoko. (2004). Manajemen Personalia dan Sumberdaya Manusia, Penerbit BPFE, Yogyakarta

Thoha, M. (2013). Perilaku Organisasi: Konsep Dasar dan Implikasinya, Jakarta: PT. Raja Grafindo Persada.

Umar, Husein., (2008). Metode Penelitian untuk Skripsi dan Tesis Bisnis. Edisi Kedua. PT RajaGrafindo Persada. Jakarta.

Wagiman S dan Himawan Arif Sutanto, (2018). Pengaruh Budaya Organisasi, Komitmen Organisasi Dan Kepuasan Kerja Terhadap Kinerja Karyawan (Studi Pada PT. Bank Rakyat Indonesia (persero) Tbk. Kantor Wilayah Semarang), Prosiding SENDI_U 2018 ISBN: 978-979-3649-99-3. http://eprints. stiebankbpdjateng.ac.id/51/

Winarno Surakhmad, (1990), Pengantar penelitian Ilmiah, Tarsito, Bandung.

Yamin, Fadel. (2017). Pengaruh Budaya Organisasi dan Komitmen Organisasi terhadap Kinerja Karyawan dengan Kepuasan Kerja Karyawan sebagai Intervening (Studi Kasus Pada Bank Mega Branch Trans Studio di Makassar). https://dspace.uii.ac.id/handle/123456789/5305. 